\section{Observations on the Spread of Mouse Polyoma Virus Infection}

The tissue culture growth of the mouse parotid tumour virus, referred to by Stewart et al. ${ }^{1}$ as "SE polyoma virus", has led to the development of rapid methods for its demonstration and determination, and to practical and specific serological techniques for antibody determinations as well ${ }^{1-5}$. We have made preliminary observations on the distribution of antibodies in various mouse colonies and on the excretion of virus.

Uninoculated mice of six breeder colonies were bled individually, and the sera tested for complement fixing and hæmagglutination inhibiting antibodies, the latter test using 16 hæmagglutinating units. Close correlation was found between the two tests ${ }^{6}$. Hæmagglutination inhibitory antibody at $1: 200$ or greater, or at $1: 100$ in serum treated with receptordestroying enzyme of $V$. cholera, was considered positive. Table 1 summarizes the frequency with which antibody was detected in mice of the various colonies. Three colonies appeared completely free of infection, while the others had infection in almost all strains tested. Antibody was found predominantly in mice more than three months of age. No evidence of strain specificity of infection was observed; for example, adult $A K R$ mice had infection-rates ranging from 5 to 100 per cent in the three infected colonies, while none of 84 adult $A K R$ mice in the Jay-Poiley colony was positive.

Table 1. Incidence of Antibony to Polyoma Viros in Six Modse COLONIES

\begin{tabular}{|c|c|c|c|}
\hline \multirow{2}{*}{ Colony } & \multicolumn{2}{|c|}{ No. of of mice positive/No. } & \multirow{2}{*}{$\begin{array}{c}\text { No. of strains } \\
\text { or sublines } \\
\text { positive/No. } \\
\text { tested }\end{array}$} \\
\hline & $\begin{array}{l}\text { 1-3 months } \\
\text { old }\end{array}$ & $\begin{array}{l}>3 \text { months } \\
\text { old }\end{array}$ & \\
\hline $\begin{array}{l}\text { Andervont (N.I.H.) } \\
\text { Gross (New York) }\end{array}$ & $1 / 61$ & $\begin{array}{r}0 / 95 \\
49 / 58\end{array}$ & $\begin{array}{l}0 / 4 \\
4 / 5\end{array}$ \\
\hline $\begin{array}{l}\text { Jackson Memorial } \\
\text { Laboratory (Bar } \\
\text { Harbor) }\end{array}$ & (2 per cent) & $\begin{array}{l}5 / 85 \\
(6 \text { per cent) }\end{array}$ & $3 / 4$ \\
\hline $\begin{array}{l}\text { Jay-Poiley (N.I.H.) } \\
\text { Law (N.I.H.) }\end{array}$ & $\begin{array}{l}0 / 539 \\
5 / 120 \\
\text { (4 }\end{array}$ & $\begin{array}{c}0 / 536 \\
149 / 406 \\
(37 \text { per cent) }\end{array}$ & $\begin{array}{r}0 / 19 \\
15 / 16\end{array}$ \\
\hline $\begin{array}{l}\text { Microbiological } \\
\text { Associates } \\
\text { (Bethesda) }\end{array}$ & & $0 / 62$ & $0 / 3$ \\
\hline
\end{tabular}

It is probably significant that two of the three negative colonies are maintained in separate quarters and by personnel who do not handle experimental mice, while the three infected colonies are located physically in proximity to experimental colonies and work with polyoma virus and mouse leukæmias, and are cared for by the same personnel. In the law colony, antibody-rates in uninoculated mice 6-11 months old were 59 per cent $(36 / 61)$ in mice in the room with new-born mice inoculated with polyoma virus, 39 per cent $(36 / 92)$ in the room with adults which received the virus as new-borns, and 13 per cent $(13 / 101)$ in a room which does not house animals inoculated with virus. Also, mice brought into our laboratory from the Jay-Poiley colony as new-borns and inoculated with uninfected control tissue culture fluids have become antibody positive after 4-6 months in about 30 per cent of individuals tested.

In the Law colony, serological conversions in mice re-bled after 2 4 months were somewhat more frequent in mice one to five months of age when bled initially (19 of 48 converted) than in mice more than six months old (12 of 47 converted).
To determine the source of the apparent environmental contamination, the following tests for virus were made. Urine and mouth swabs were taken from 8 mice which had been inoculated with virus as newborns five to ten weeks previously; these mice were in five different cages, and the bedding and drinking water of each cage were also sampled. The virus detection procedure employed was based on the production of antibody in adult mice inoculated intraperitoneally (mouse antibody production test); this procedure has been found to be highly sensitive for detection of virus ${ }^{6}$. A suspension of the material tested was inoculated intraperitoneally into three weanling mice from the Jay-Poiley colony, and three weeks later their sera were tested for hæmagglutination-inhibiting antibody. 84 control mice inoculated with seline were distributed in the jars with the test mice, and none developed antibody. Seven of the eight urine specimens were positive for virus, as were all eight mouth swabs, all five bedding samples, and four of the five drinking bottles.

Inhalation may be the means of entry, since we have found that mice can be infected as new-borns or adults by intranasal instillation of $10^{2}$ to $10^{3}$ intraperitoneal immunizing doses, but as yet we have not been able to infect by feeding.

These results suggest that environmental contamination is important in the spread of polyoma virus, and that cross-infection is to be expected in laboratories working with the agent. The implication that infection is generally acquired at several months of age would explain the rarity of spontaneous occurrence of the characteristic parotid tumours, even in infected colonies ${ }^{7,8}$, since, experimentally, tumours can be produced only by inoculation of suckling mice. The great variation in polyoma infection-rates in various $A K R$ stocks indicates that polyoma virus bears no etiological relation to spon. taneous $A K R$ leukæmia, despite their repeated association ${ }^{8}$, since high leukæmia-rates are found in all $A K R$ stocks.

Wallace P. Rowe

JANET W. HARTLEY

ISADORE BRODSKY

ROBERT J. HUEBner

National Institute of Allergy and Infectious Diseases,

LLOYD W. LAW

National Cancer Institute,

National Institutes of Health,

Bethesda, Maryland. Sept. 26.

1 Stewart, S. E., Eddy, B. E., and Borgese, N., J. Nat. Cancer Inst., 20, 1223 (1958)

${ }^{2}$ Eddy, B. E., Stewart, S. E., Young, R., and Mider, G. B., J. Nat. Cancer Inst., 20,747 (1958).

${ }^{3}$ Eddy, B. E., Rowe, W. P., Hartley, J. W., Stewart, S. E., and Huebner, R. J, Virology, 6, 290 (1958).

${ }^{4}$ Eddy, B. E., Stewart, S. E., and Berkeley, W. H., Proc. Soc. Exp. Biol. Med., 98, 848 (1958).

${ }^{5}$ Rowe, W. P., Hartley, J. W., Brodsky, I., and Huebner, R. J., Seience (in the press).

- Rowe, W. P., et al. (in preparation).

' Law, L. W., Ann. N.Y. Acad. Sci., 68, 616 (1957).

${ }^{8}$ Gross, L., Cancer Res., 18, 371 (1958).

\section{Biochemical Changes in Virus-infected and Regenerating Mouse Liver}

THE biochemical changes accompanying the multiplication of an animal virus within its host cell are still largely unknown. Alterations in the levels of activity of a variety of enzymes in mouse brain infected with virus have been reported by Bauer ${ }^{1}$. 